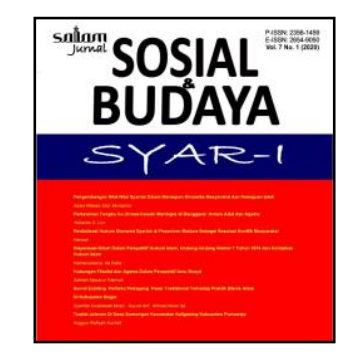

P-ISSN: 2356-1459. E-ISSN: 2654-9050

Vol. 8 No. 4 (2021), pp. 1067-1082

DOI: 10.15408/sjsbs.v8i4.20918

http://journal.uinjkt.ac.id/index.php/salam/index

\title{
Dampak Pengejawantahan Permenkumham Nomor 10 Tahun 2020 di BAPAS Klas I Bandung*
}

\author{
Vivi Sylviani Biafri ${ }^{1}$ \\ Politeknik Ilmu Pemasyarakatan Indonesia \\ 10.15408/sjsbs.v8i4.20918
}

\begin{abstract}
Efforts to anticipate the spread of Covid-19 in prisons are to provide social integration rights to prisoners and children according to applicable regulations. This was realized by the passing of a ministerial regulation related to Covid-19. This policy taken by the government caused anxiety in the community. This is because many prisoners who have been released have committed crimes again. This study uses a qualitative method with a descriptive approach. The research question is how the impact of the implementation of Permenkumham No. 10 of 2020 in Bandung Prison, and what are the factors that cause PK to not be optimal in carrying out their duties? The results showed that the absence of community research (LITMAS) resulted in Community Guidance (PK) not being able to carry out their duties optimally.
\end{abstract}

Keywords: BAPAS; Covid-19; Social Integration

\begin{abstract}
Abstrak
Upaya antisipasi meluasnya Covid-19 di lapas adalah memberikan hak integrasi sosial kepada narapidana dan anak sesuai peraturan yang berlaku. Ini diwujudkan dengan disahkannya peraturan menteri terkait Covid-19. Kebijakan yang diambil oleh pemerintah ini menimbulkan kecemasan di masyarakat. Hal ini disebabkan banyak napi yang sudah bebas kembali melakukan tindak pidana. Penelitian ini menggunakan metode kualitatif dengan pendekatan deskriptif. Pertanyaan penelitiannya bagaimana dampak pelaksanaan Permenkumham No. 10 Tahun 2020 di Lapas Bandung, serta faktor-faktor apa saja yang menyebabkan PK tidak maksimal dalam menjalankan tugasnya? Hasil penelitian menunjukkan tidak adanya penelitian kemasyarakatan (LITMAS) mengakibatkan Pembimbingan Kemasyarakatan (PK) tidak dapat melaksanakan tugas secara maksimal.

Kata Kunci : BAPAS; Covid-19; Integrasi Sosial
\end{abstract}

\footnotetext{
${ }^{*}$ Received: May 03, 2021, Revision: May 25, 2021, Published: August 5, 2021.

${ }^{1}$ Vivi Sylviani Biafri adalah peneliti pada Politeknik Ilmu Pemasyarakatan. Jl. Raya Gandul Cinere No. 4 Depok Cinere. Email: vivi_biafri@yahoo.com
} 


\section{A. PENDAHULUAN}

Penyebaran virus Corona yang sangat cepat perlu diantisipasi oleh jajaran Kementerian Hukum dan HAM. Salah satu Unit Eselon I yang terdampak virus ini dan sangat rentan terpapar adalah Ditjen PAS. Ditjen PAS mempunyai UPT PAS sebanyak 525 Lapas/Rutan dan 90 Bapas yang tersebar di seluruh Indonesia. Keadaan lapas dan rutan di seluruh Indonesia umumnya over crowded. Kondisi over crowded memudahkan terjadinya penularan virus Corona secara cepat diantara para narapidana. Penularan ini dapat terjadi dari petugas kepada narapidana atau dari keluarga narapidana yang membesuk. Untuk menekan meluasnya virus corona di UPT PAS maka diambil kebijakan oleh pimpinan untuk mempercepat pemberian hak integrasi sosial bagi napi dan anak. Keputusan tersebut diwujudkan dengan mengeluarkan Permenkumham pemberian hak integrasi sosial masa pandemik. Permenkumham ini mengatur mengenai syarat dan SOP pemberian hak integrasi sosial masa pandemik covid-19.

Dalam pelaksanaannya Peraturan Menteri ini menimbulkan keresahan di dalam masyarakat. Keresahan terjadi karena narapidana yang sudah bebas kembali melakukan tindak kriminal. Akibatnya terjadi peningkatan angka kriminalitas dan menimbulkan kekhawatiran di masyarakat. Berdasarkan data dari Direktorat Jenderal Pemasyarakatan Bulan Januari 2021 seluruh Indonesia jumlah yang mendapatkan asimilasi rumah sebanyak 69.505 dan yang memperoleh $\mathrm{PB}, \mathrm{CMB}$ dan $\mathrm{CB}$ ada 30.000 dari periode April- Desember 2020. ${ }^{2}$

Jumlah yang dibebaskan cukup banyak sehingga menimbulkan kekhawatiran di masyarakat. Kekhawatiran masyarakat tersebut semakin bertambah dengan adanya pemberitaan di surat kabar. Pemberitaan yang muncul di media massa terkait narapidana yang dibebaskan karena covid-19 kembali melakukan pengulangan. Kombes Pol Ahmad Ramadhan sebagai Kabag Penerangan Umum Polri, Senin tanggal 25 Mei 2020 mengatakan bahwa ada 135 narapidana yang memperoleh asimilasi dan integrasi masa pandemik covid kembali melakukan pengulangan tindak pidana ${ }^{3}$. Lombok Post pada bulan Juli 2020 juga memberitakan tentang narapidana yang bebas karena covid-19 kembali melakukan kejahatan. ${ }^{4}$ Data bulan Desember 2020 menunjukkan bahwa klien Bapas Bandung yang bebas karena corona virus ada 29 orang yang melakukan pengulangan tindak pidana. Dua puluh sembilan klien tersebut yang bebas menjalani asimilasi rumah ada 24 orang, cuti bersyarat ada 2 orang dan pembebasan bersyarat 2 orang. Banyaknya kasus kejahatan yang dilakukan oleh napi yang bebas karena permenkumham tersebut menyebabkan banyak gugatan

\footnotetext{
“Instagram

Direktorat

Jenderal

Pemasyarakatan,"

n.d., https://www.instagram.com/p/CJvebM1LEMn/?igshid=wbdhpr9d7f5.

3 “135 Napi Asimilasi Kambuh," 2020, https://www.cnnindonesia.com/nasional/2020052608122712-506870/135-napi-asimilasi-kambuh-dari-faktor-ekonomi-hingga-dendam.

4 “Berulah Lagi, Napi Asimilasi Bakal Lebih Lama Dipenjara," n.d., https://lombokpost.jawapos.com/kriminal/29/07/2020/berulah-lagi-napi-asimilasi-bakal-lebih-lamadipenjara/.
} 
dari masyarakat salah satunya dari Yayasan Mega Bintang Indonesia. ${ }^{5}$ Ini menunjukkan bahwa proses pembimbingan dan pengawasan oleh pembimbing kemasyarakatan tidak maksimal. Penyebab tidak maksimalnya pembimbingan dan pengawasan oleh PK harus segera diketahui sehingga tidak terjadi lagi.

Anak dan napi setelah bebas dari lapas atau LPKA menjadi klien Bapas. Bapas yang akan melaksanakan tugas pembimbingan, pendampingan dan pengawasan. Tugas tersebut dilaksanakan oleh pembimbing kemasyarakatan (PK).

Peraturan mengenai pemberian hak integrasi sosial masa pandemik corona virus merupakan kebijakan dan produk hukum. "Kebijakan" terjemahan dari bahasa Inggris policy. Pada umumnya berhubungan dengan aturan yang ditetapkan oleh pemerintah. Pemerintah mempunyai power untuk memberikan arah kepada warganegaranya dan bertanggungjawab memberikan pelayanan publik. ${ }^{6}$ Sebuah kebijakan yang telah disusun secara teliti dan disahkan maka akan diimplementasikan di lapangan untuk menyelesaikan masalah yang ada agar tujuan yang telah ditetapkan tercapai. Sebuah kebijakan yang telah diimplementasikan dapat dianalisis.

Teori Implementasi yang dikemukakan oleh Edward III menyatakan bahwa ada 4 hal dalam implementasi kebijakan, yaitu komunikasi, sumber daya, disposisi atau sikap, and struktur birokrasi. ${ }^{7}$ Adapun penjelasannya sebagai berikut:

1. Komunikasi

Komunikasi mempunyai peran yang sangat penting. Perintah untuk melaksanakan kebijakan harus disampaikan secara jelas untuk membentuk persepsi yang sama dan memperkecil terjadinya kesalahan. Komunikasi dibagi menjadi dua. Pertama, komunikasi formal adalah komunikasi yang dibentuk pada jalur-jalur formal dalam suatu organisasi publik yang ditetapkan melalui struktur organisasi. Kedua, komunikasi non formal, adalah komunikasi melalui cara non formal, bersifat insidental, berdasarkan hubungan personal yang baik, atau mempunyai kepentingan yang sama. ${ }^{8}$

2. Sumber daya

Berkaitan dengan sumber daya manusia (SDM), termasuk SDM yang mampu mendukung terlaksananya penerapan aturan yang telah ditetapkan. Diharapkan SDM yang memiliki kapasitas, motivasi dan mempunyai kualifikasi yang baik akan sangat membantu terwujudnya penerapan aturan secara tepat, efektif dan efisien. ${ }^{9}$

5 “Napi Dilepas Bikin Resah,” n.d., https://www.cnnindonesia.com/nasional/20200426173911-12497429/napi-dilepas-bikin-resah-kebijakan-asimilasi-yasonna-digugat.

${ }^{6}$ Rayambong Sumuang Sitohang and Kariono, "Implementasi Peraturan Pemerintah Nomor 65 Tahun 2010 Tentang Sistem Nformasi Keuangan Daerah Pada Pemerintah Kabupaten Dairi" 5, no. 2 (2015), http://ojs.uma.ac.id/index.php/adminpublik/article/view/72/30.

${ }^{7}$ Yulianto Prof. Dr. Kadji, Formulasi Dan Implementasi Kebijakan Publik: Kepemimpinan Dan Perilaku Birokrasi Dalam Fakta Realitas, pertama (Gorontalo: Universitas Negeri Gorontalo Press, 2015).

8 Ibid, 65.

${ }^{9} \mathrm{Ibid}, 66$. 


\section{Disposisi}

Disposisi atau sikap pegawai adalah hal yang sangat penting dalam proses penerapan sebuah peraturan. Pelaksanaan peraturan dapat berjalan baik, jika pegawai memahami dan mengetahui apa yang harus dilaksanakan, mempunyai kemampuan untuk melakukannya dan mempunyai sikap positif untuk melaksanakan kebijakan tersebut. ${ }^{10}$ Sikap positif antara lain komitmen, kejujuran, tanggung jawab, inovatif, demokratis dan lain-lain.

4. Struktur Birokrasi

Struktur birokrasi mempunyai peran yang besar dalam penerapan sebuah aturan. Struktur organisasi yang besar cenderung lemah dalam pengawasan. Sistem birokrasi yang berbelit-belit dan kompleks menyebabkan organisasi tidak fleksibel. Oleh karena itu standard operating procedur (SOP) yang jelas dan rinci sangat dibutuhkan. ${ }^{11}$

Kebijakan terkait pembebasan narapidana karena covid seharusnya menyelesaikan masalah namun di sisi lain menimbulkan masalah baru. Masalah tersebut diantaranya tugas pembimbing kemasyarakatan yang menjadi tidak optimal. Hal ini harus diketahui faktor penyebabnya. Pertanyaan penelitian yang diajukan adalah bagaimana dampak pelaksanaan Permenkumham No. 10 Tahun 2020 di Bapas Klas I Bandung, serta faktor-faktor apa saja yang menyebabkan PK tidak maksimal dalam menjalankan tugas bimbingan dan pengawasan? Penelitian ini untuk mengetahui dan menganalisis akibat muncul dari pelaksanaan permenkumham tersebut dan faktor-faktor yang menyebabkan PK tidak dapat melaksanakan tugas secara maksimal.

Berdasarkan uraian diatas maka judul penelitian yang diambil Dampak Pelaksanaan Permenkumham Nomor: 10 Tahun 2020 di Bapas Klas I Bandung. Penelitian terkait Peraturan Menteri Hukum dan Ham ini telah banyak dilakukan diantaranya adalah tentang pelaksanaan tugas pembimbing kemasyarakatan di masa pandemik covid-19 dilakukan oleh Enny Umronah. Penelitian ini mengkaji tentang pengawasan yang dilaksanakan pada masa pandemik covid-19 bagi klien pemasyarakatan dari sisi yuridis. ${ }^{12}$ Penelitian yang dilakukan oleh Enny Umronah membahas tentang proses pengawasan di masa sebelum dan masa pandemik covid-19 beserta dasar hukumnya di Bapas Malang. Kedua, penelitian yang dilakukan oleh Moh. Zakaria dan Sri Sulistijaningsih membahas dari sisi hukum positif terhadap pelaksanaan asimilasi di rumah. ${ }^{13}$

${ }^{10}$ Ibid, 68.

${ }^{11}$ Ibid, 69.

12 Enny Umronah, “Analisis Yuridis Pengawasan Asimilasi Dan Integrasi Bagi Narapidana Dan Anak Ketika Pandemi Covid-19 (Studi Di Balai Pemasyarakatan Kelas I Malang) -Enny," Legal Spirit 4 (2020), https://publishing-widyagama.ac.id/ejournal-v2/index.php/jhls/article/view/1554/1171.

${ }^{13}$ Moh dan Sri Sulistijaningsih Zakaria, "Tinjauan Hukum Terhadap Pelaksanaan Asimilasi Di Rumah Berdasarkan Keputusan Menteri Hukum Dan Ham Republik Indonesia Nomor M.HH19.PK.01.04.04 Tahun 2020 Dalam Rangka Pencegahan Dan Penanggulangan COovid-19 Bagi Narapidana," Era Hukum 18 (2020): 156-81, https://journal.untar.ac.id/index.php/hukum/article/view/9932. 
Perbedaan antara kedua penelitian tersebut dengan penelitian saya adalah pertama, penelitian ini membahas tentang dampak yang terjadi dari pelaksanaan Permenkumhan mengenai pemberian hak integrasi sosial masa pandemik di Bapas Klas I Bandung. Kedua, penelitian ini ingin mengetahui faktor penyebab pembimbingan dan pengawasan terhadap klien yang bebas karena permenkumham ini tidak berjalan maksimal.

\section{B. METODE PENELITIAN}

Penelitian ini menggunakan metode kualitatif. According to Denzim and Lincoln, the word qualitative emphasizes the research process and the implied meaning. ${ }^{14}$ Menurut John W.Creswell penelitian kualitatif adalah penyelidikan pemahaman yang didasarkan pada tradisi metodologis penelitian yang menggali permasalahan sosial atau kemanusiaan. Peneliti harus memiliki gambaran yang kompleks dan holistik terhadap masalah yang diteliti, melakukan analisis kata-kata, mempelajari hasil wawancara dengan informan, serta melakukan observasi lapangan. Penelitian kualitatif adalah proses meneliti secara mendalam tentang suatu masalah sosial dengan tetap mengikuti tahapan metode penelitian ilmiah. ${ }^{15}$

Data penelitian diperoleh dari 2 sumber data yaitu primer dan sekunder. Data primer didapat dengan melakukan wawancara kepada para PK serta Kepala Bapas Klas I Bandung sebagai subyek penelitian dan melakukan observasi di lapangan. Data sekunder diperoleh dengan membaca literatur jurnal, semua peraturan mengenai pemberian hak integrasi sosial masa pandemik dan berita. Teknik pengumpulan data dengan melakukan deep-interview, pengamatan di lapangan dan studi literatur.

Penelitian dilaksanakan di Bapas Klas I Bandung. Alasan dipilihnya menjadi lokasi penelitian karena Bapas Klas I Bandung memiliki wilayah tugas yang luas terdiri dari tiga kota dan empat kabupaten sehingga permasalahan yang dihadapi lebih kompleks.

Teknik analisa data dalam penelitian ini berdasarkan pendapat Robert K. Yin yang terdiri dari 5 tahapan yaitu: (1) Compiling, (2) Disassembling, (3) Reassembling (and Arraying), (4) Interpreting, and (5) Concluding. ${ }^{16}$ Dapat dilihat pada gambar di bawah ini:

${ }^{14}$ Kusmiyanti and Vivi Sylviani : “Impact of Over-Crowding In Correctional Institution On Health of Prisoner". Proceeding The International Conference On Social Work (ICSW), 2019:

3.

${ }^{15}$ Kusmiyanti Biafri, Vivi Sylviani, "Impact of Over-Crowding In Correctional Institution On Health of Prisoner," in International Conference On Social Work In Health and Mental Health, 2018.

${ }^{16}$ Robert K. Yin, Qualitative Research from Start to Finish, 2nd ed. (New York: The Guilford Press, 2016). 


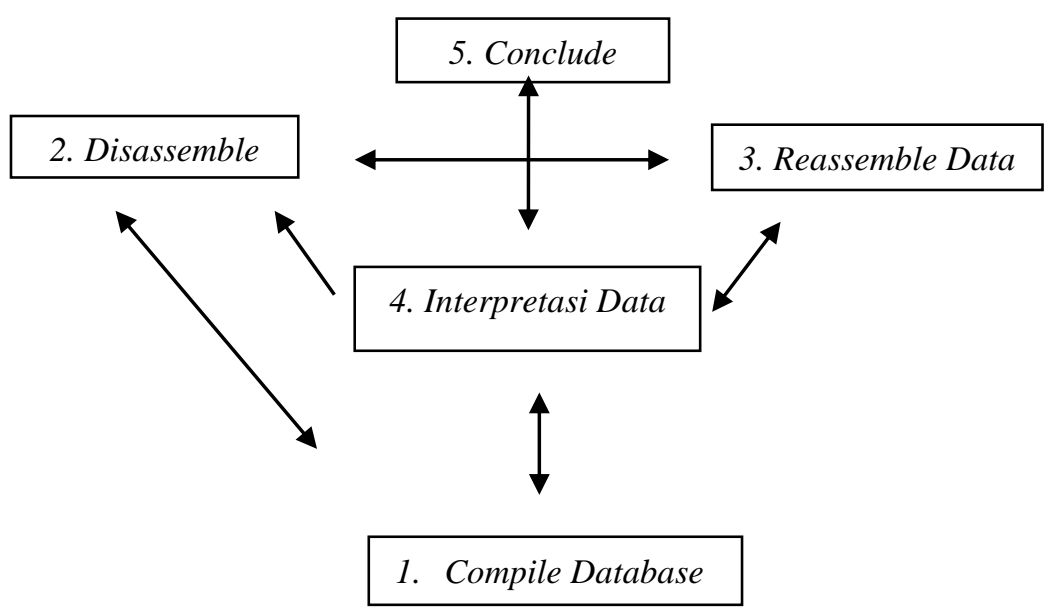

\section{HASIL TEMUAN DAN PEMBAHASAN}

\section{Bapas Klas I Bandung}

Bapas merupakan institusi yang melakukan bimbingan terhadap klien pemasyarakatan. ${ }^{17}$ Ada 2 jenis bapas yaitu klas I dan II. Bapas Klas I Bandung dipimpin oleh Kabapas eselon III a. Di bawah Kepala Bapas terdapat eselon IV b dan eselon V. Struktur organisasinya terdiri dari: ${ }^{18}$

a. Subbag TU, dipimpin oleh seorang pejabat eselon IV b. Kasubag Tata Usaha membawahi 3 eselon V yaitu Kaur Kepegawaian, Kaur Keuangan dan Kaur Umum.

b. Seksi bimbingan klien dewasa, dipimpin seorang pejabat eselon IV b. Kasi Bimbingan Klien Dewasa membawahi 3 eselon V yaitu Kasubsi Registrasi Klien Dewasa, Kasubsi Bimbingan Kemasyarakatan Klien Dewasa dan Kasubsi Bimkerja Klien Dewasa.

c. Seksi bimbingan klien anak, dipimpin seorang pejabat eselon IV b. Kasi Bimbingan Klien Anak membawahi Kasubsi Registrasi Klien Anak, Kasubsi Bimkemas Klien Anak serta Kasubsi Bimkerja Klien Anak.

Sebagai institusi pemerintah, bapas mempunyai tugas dan fungsi. Tugas bapas meliputi :

a. Melakukan bimbingan kepada napi dan anak berdasarkan peraturan perundang-undangan.

b. Melakukan pembinaan, pendampingan, pembimbingan dan pengawasan klien di Bapas.

Fungsi bapas antara lain: ${ }^{19}$

17 “Undang-Undang No. 12 Tahun 1995 Tentang Pemasyarakatan,” n.d.

18 "Keputusan Menteri Kehakiman RI No. M.02-PR.07.03 Tahun 1987 Tentang Organisasi Dan Tata Kerja Balai Bimbingan Kemasyarakatan Dan Pengentasan Anak," 1987.

19 "Keputusan Menteri Kehakiman RI No. M.02-PR.07.03 Tahun 1987 Tentang Organisasi Dan Tata Kerja Balai Bimbingan Kemasyarakatan Dan Pengentasan Anak." 
a. Melayani permintaan penelitian kemasyarakatan untuk bahan penentuan program pembinaan bagi narapidana dan anak atas dasar permintaan dari Lapas, Rutan dan Bapas lain.

b. Pelaksanaan registrasi klien pemasyarakatan.

c. Memberikan program bimbingan bagi klien.

d. Menghadiri sidang anak di PN dan sidang TPP di Bapas, Lapas dan Rutan.

e. Melaksanakan bimbingan kepribadian, sosial dan latihan kerja, baik yang diselenggarakan sendiri ataupun bekerja sama dengan instansi terkait; dan

f. Menyelenggarakan urusan tata usaha Bapas

Ujung tombak dalam pelaksanaan tugas bapas adalah Pembimbing Kemasyarakatan (PK). Sejak tahun 2016 PK sudah menjadi jabatan fungsional tertentu (JFT) berdasarkan Permenpan RB tahun 2016 mengenai JFT PK.

Berdasarkan data bulan Maret 2021 Bapas Klas I Bandung memiliki sumber daya manusia sebanyak 94 (sembilan puluh empat) pegawai yang terdiri dari pejabat struktural ada 13 (tiga belas) orang, jabatan fungsional umum ada 19 (sembilan belas) orang, Asisten Pembimbing Kemasyarakatan (APK) ada 3 (tiga) orang dan PK ada 59 (lima puluh sembilan) orang. Wilayah tugas Bapas Klas I Bandung meliputi tiga kota dan empat kabupaten yaitu Kotamadya Bandung, Kab. Bandung, Kab. Bandung Barat, Kotamadya Cimahi, Kab. Cianjur, Kab. Sukabumi dan Kotamadya Sukabumi.

\section{Tugas Pembimbing Kemasyarakatan}

Petugas Pemasyarakatan yang bertugas di Bapas disebut PK, penunjukan, pengangkatan dan pemberhentiannya menjadi PK oleh Menteri berdasarkan peraturan perundang-undangan. ${ }^{20}$ Keputusan Menteri Kehakiman tahun 1998 juga menjelaskan tentang tugas PK adalah: ${ }^{21}$

1) Melayani litmas untuk:

a. Menangani perkara anak naka yang bekerja sama dengan Penyidik, Penuntut Umum dan Hakim;

b. Menyusun program pembinaan kemandirian dan kepribadian bagi narapidana dan Andikpas;

c. Menyusun program perawatan bagi tahanan;

d. Menyusun program pembimbingan;

2) Melaksanakan bimbingan kepribadian dan kemandirian;

3) Melaksanakan layanan bagi instansi dan kelompok tertentu (peneliti) yang membutuhkan data atau hasil litmas;

20 Direktorat Jenderal Pemasyarakatan, Kompilasi Peraturan Perundang-Undangan Tentang Pembimbingan, 2015.

${ }^{21}$ Pemasyarakatan. 
4) Mengkoordinir peksos dan pekerja sosial masyarakat yang melakukan bimbingan; dan

5) Melakukan pengawasan bagi anak yang dijatuhi pidana bersyarat dan yang dikembalikan kepada orang tua/wali.

Undang-Undang SPPA menjelaskan bahwa PK merupakan pejabat fungsional penegak hukum yang mempunyai tugas melakukan pembuatan litmas, pembimbingan, pengawasan, dan pendampingan bagi Anak dari tahap pra adjudikasi sampai post adjudikasi.22 Berdasarkan Permenpan RB mengenai Jabatan Fungsional PK, dijelaskan bahwa PK adalah PNS yang mempunyai tugas melakukan kegiatan bimbingan kemasyarakatan. ${ }^{23}$ Bimbingan kemasyarakatan adalah kegiatan yang berkaitan dengan tugas PK dalam membantu menyelesaikan masalah, yang meliputi pembuatan litmas, pendampingan, pembimbingan, pengawasan, dan menghadiri sidang TPP. Undang-Undang SPPA juga menjelaskan tentang tugas PK sebagai berikut: ${ }^{24}$

1) Penelitian Kemasyarakatan

Penyusunan litmas merupakan kegiatan yang dilakukan PK untuk mengetahui latar belakang kehidupan narapidana dan anak.

2) Pendampingan

Pendampingan merupakan tugas PK untuk membantu Anak dari tahap penyidikan, penuntutan, pengadilan serta setelah bebas sehingga Anak mengalami perubahan ke arah yang lebih baik.

3) Pembimbingan

Kegiatan yang dilakukan PK untuk meningkatkan ketakwaan klien terhadap Sang Pencipta, intelektual, tingkah laku, kesehatan jasmani dan rohani yang dilakukan secara profesional.

Pelaksanaan pembimbingan dilakukan dengan tiga tahapan yakni tahap awal, tahap lanjutan dan tahap akhir, yaitu: ${ }^{25}$

a) Tahap awal

Tahap ini dimulai sejak nol masa bimbingan sampai dengan $1 / 4$ (satu perempat) masa pembimbingan. PK pada tahap ini membuat litmas, menyusun program bimbingan, pelaksanaan program, mengevaluasi pelaksanaan program dan menyusun rencana bimbingan tahap lanjutan berdasarkan hasil evaluasi.

b) Tahap lanjutan

22 “UU NO. 11 Tahun 2012 Tentang Sistem Peradilan Pidana Anak," 2012.

23 "PERMENPAN NO 22 Tahun 2016 Tentang Jabatan Fungsional Pembimbing Kemasyarakatan.Pdf," n.d.

24 "UU NO. 11 Tahun 2012 Tentang Sistem Peradilan Pidana Anak."

25 "Peraturan Pemerintah No. 31 Tahun 1999 Tentang Pembinaan Dan Pembimbingan Wargabinaan Pemasyarakatan," n.d. 
Tahap ini dimulai sejak berakhirnya tahap awal sampai dengan $3 / 4$ (tiga perempat) masa bimbingan. PK pada tahap ini melaksanakan program bimbingan, mengevaluasi pelaksanaan program dan menyusun rencana bimbingan tahap akhir berdasarkan hasil evaluasi.

c) Tahap akhir

Tahap ini dilakukan sejak berakhirnya bimbingan tahap lanjutan sampai dengan berakhirnya masa pembimbingan.

\section{4) Pengawasan}

Kegiatan ini dilakukan secara langsung maupun tidak langsung. Secara langsung PK melakukan home visit dan secara tidak langsung PK berkoordinasi dengan pihak terkait.

Dengan terjadinya pandemik covid-19 ini maka PK dalam menjalankan tugasnya juga mengalami perubahan. Tugas PK di masa pandemik ini dilakukan dengan daring. Pembuatan litmas, pendampingan, pembimbingan dan pengawasan secara daring melibatkan klien dan keluarganya, pihak RT/RW bahkan juga polres dan polsek untuk membantu pengawasan mereka. Hal ini sejalan dengan kebijakan dari Direktorat Jenderal Pemasyarakatan. Pedoman ini dikeluarkan untuk menjaga PK agar tidak rentan terpapar covid-19.

Penelitian kemasyarakatan/litmas secara daring dilaksanakan dengan mekanisme sebagai berikut ${ }^{26}$ :

a. Dokumen klien yang dikirimkan secara daring oleh instansi pemohon (Lapas/LPKA/Rutan/kepolisian) dipelajari oleh PK/APK.

b. Melaksanakan koordinasi untuk menentukan jadwal wawancara dengan klien secara daring.

c. Wawancara daring dengan klien dan/atau wali/petugas menggunakan sarana telepon/video call/media daring lainnya, untuk memperoleh data tentang riwayat hidup klien, latar belakang tindak pidana, kondisi keluarga/penjamin dan lingkungan tempat tinggal klien.

d. Penggalian data informasi mengenai keluarga/penjamin klien, kepada pemerintah setempat, dan pihak terkait dilakukan secara daring.

e. Observasi kondisi tempat tinggal klien/penjamin dan lingkungan sekitarnya dilakukan dengan video call disertai bukti dokumentasi berupa foto dan/atau video.

f. Keluarga/penjamin tidak memiliki sarana untuk penggalian data dan observasi secara daring, Pembimbing Kemasyarakatan/Asisten Pembimbing Kemasyarakatan berkoordinasi dengan instansi pemohon, pemerintah setempat

${ }^{26}$ Direktorat Jenderal Pemasyarakatan, “Pedoman Pelaksanaan Penelitian Kemasyarakatan Dan Pendampingan Secara Daring Serta Pembimbingan dan Pengawasan Klien Asimilasi dan Integrasi Dalam Rangka Pencegahan Dan Penanggulangan Covid-19," 2020. 
(Lurah/RW/RT), pamong atau Pokmas Bapas yang ada di lingkungan tempat tinggal keluarga / penjamin klien untuk memfasilitasi.

g. Konsep laporan Litmas yang dibuat oleh PK/APK dibahas dalam sidang TPP secara daring.

h. Konsep laporan Litmas hasil sidang TPP diserahkan kepada JFT PK satu jenjang diatasnya untuk dianalisis dan dievaluasi, kemudian diteruskan kepada atasan langsung/Kabapas untuk dikoreksi secara berjenjang melalui email/ whatsapp/sumaker.

i. Laporan litmas yang telah dikoreksi kemudian diperbaiki oleh PK/APK setelah itu ditandatangani secara digital dan disampaikan kembali kepada atasan/Kabapas untuk mendapat persetujuan dalam aplikasi sumaker.

j. Litmas yang telah disetujui dan ditandatangani oleh Kabapas diberi barcode dan nomor surat oleh operator sumaker kemudian didistribusikan.

Untuk lebih jelas pelaksanaan litmas secara daring prosedurnya dapat dilihat pada gambar di bawah ini: ${ }^{27}$

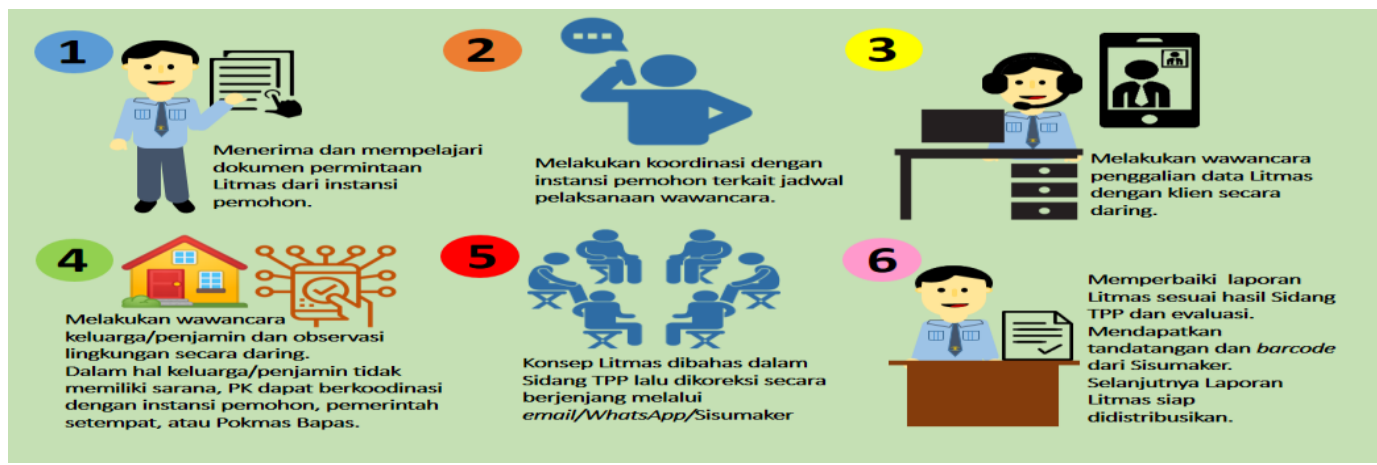

Pelaksanaan pendampingan oleh PK secara daring dilaksanakan dengan mekanisme sebagai berikut: ${ }^{28}$

a. Dokumen klien yang dikirimkan secara daring oleh instansi pemohon (Lapas/LPKA/Rutan/kepolisian) dipelajari oleh PK/APK.

b. Melaksanakan koordinasi dengan instansi terkait untuk menentukan jadwal pendampingan secara daring.

c. Pendampingan secara daring menggunakan sarana video call/media daring lainnya bagi keperluan pemeriksaan, musyawarah diversi, pelimpahan berkas, persidangan, putusan pengadilan/hakim, pemenuhan kebutuhan/intervensi berdasarkan hasil asesmen, dll.

d. Keluarga/penjamin tidak memiliki sarana untuk dilakukan pendampingan secara daring, Pembimbing Kemasyarakatan/Asisten Pembimbing Kemasyarakatan dapat berkoordinasi dengan instansi pemohon, pemerintah

\footnotetext{
${ }^{27}$ Pemasyarakatan.

${ }^{28}$ Pemasyarakatan.
} 
setempat (Lurah/RW/RT), pamong atau Pokmas Bapas yang ada di lingkungan tempat tinggal keluarga / penjamin klien untuk memfasilitasi.

e. Pembimbing Kemasyarakatan/Asisten Pembimbing Kemasyarakatan membuat catatan dan dokumentasi serta membuat laporan hasil pendampingan.

Pelaksanaan bimbingan klien dilakukan mulai dari tahap penerimaan dan pendaftaran klien yang dilakukan secara daring. PK kemudian menyusun rencana bimbingan terhadap klien yang dilakukan secara daring. Setelah rencana bimbingan tersusun maka bimbingan terhadap klien dapat dilaksanakan. Adapun pelaksanaan bimbingan secara daring sebagai berikut ${ }^{29}$ :

1) Bimbingan dilakukan secara daring menggunakan aplikasi video call/zoom selama masa pandemik Covid-19 belum dinyatakan berakhir oleh pemerintah;

2) Bimbingan dilakukan sesuai jadwal yang telah disepakati antara PK/APK dengan klien dengan memanfaatkan sarana telepon/sms/whatsapp/video call;

3) Klien selama proses bimbingan wajib ;

a) Keberadaannya tetap di rumah;

b) Menjaga kesehatan diri sendiri dan orang di sekitarnya;

c) Tidak mengulangi tindak pidana;

d) Mematuhi syarat khusus dan umum;

e) Terlibat dalam penanggulangan corona virus.

4) Pembimbing Kemasyarakatan/Asisten Pembimbing Kemasyarakatan bekerja sama dan berkoordinasi dengan instansi terkait dalam proses bimbingan;

5) Selama proses bimbingan PK/APK mencatat ke kartu bimbingan, hasil bimbingan yang dicapai dan daftar hadir diparaf oleh PK/APK;

6) Setiap tahap bimbingan PK/APK membuat laporan perkembangan sesuai dengan mekanisme daring;

7) Klien wajib mengirimkan foto dan/atau video aktivitas ke PK/APK sebagai data dukung laporan pelaksanaan bimbingan daring;

8) Klien yang tidak mempunyai sarana untuk mengirimkan foto/video secara daring maka PK/APK berkoordinasi dengan pihak RT/RW/Kelurahan untuk mengirimkan foto/video aktivitasnya;

9) Informasi yang wajib disampaikan PK/APK kepada klien terkait corona virus, adalah :

a) Gejala umum orang yang terpapar covid adalah demam diatas 37,5 derajat Celsius, batuk, napas pendek, radang tenggorokan, dan lain-lain.

b) Selalu rajin mencuci tangan dengan sabun dan air mengalir ataupun hand sanitizer;

\footnotetext{
${ }^{29}$ Pemasyarakatan.
} 
c) Menjaga jarak dengan orang lain;

d) Penggunaan peralatan makanan, obat, kontak fisik yang erat berpotensi menyebarkan Covid.

e) Klien wajib menggunakan masker.

Tatapan pelaksanaan pembimbingan dapat dilihat pada gambar berikut ini :

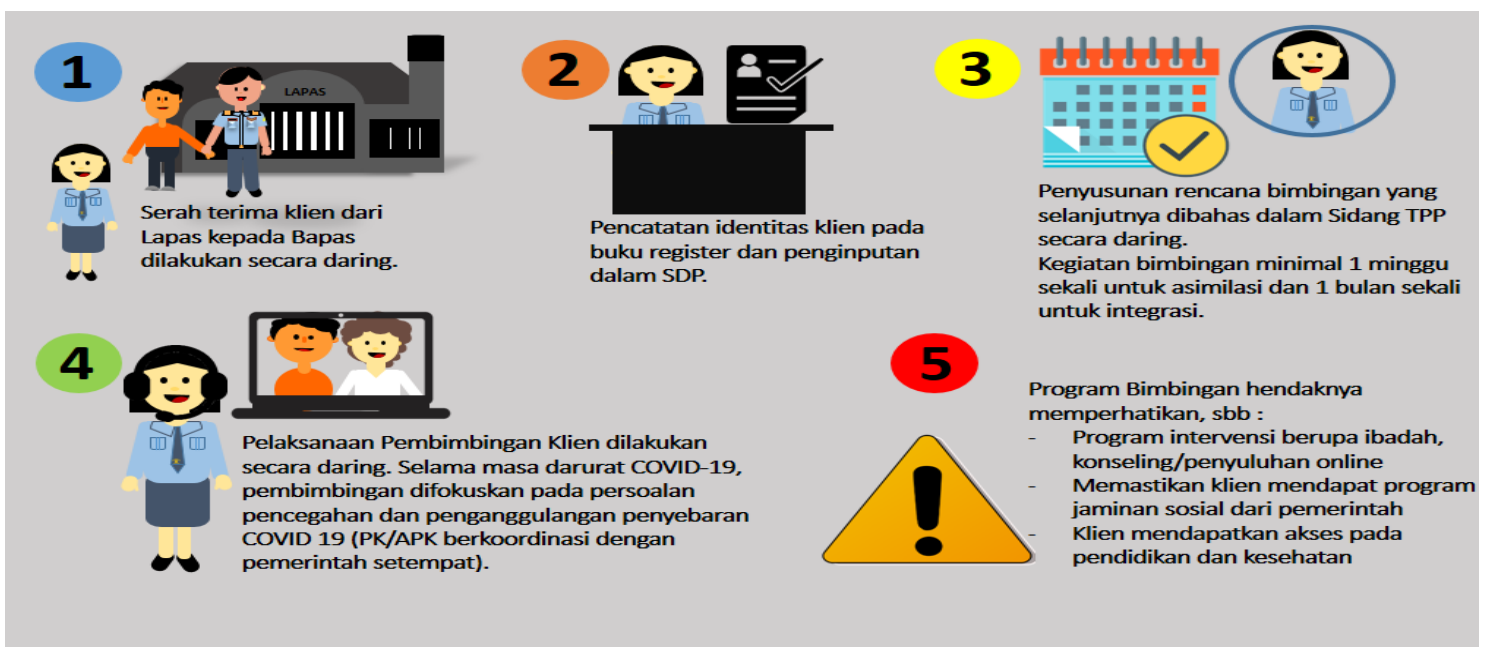

Sebelum pengawasan terhadap klien dilakukan maka PK wajib menyusun rencana pengawasan yang dilakukan secara daring. Dalam penyusunan program pengawasan ini PK juga harus memastikan siapa saja pihak atau instansi yang akan terlibat dalam pengawasan klien. Klien yang melakukan pelanggaran akan mendapatkan sanksi. Untuk lebih jelasnya tahapan pengawasan klien secara daring dapat dilihat pada gambar berikut ini ${ }^{30}$ :

1) Pengawasan dilaksanakan secara daring dengan menggunakan aplikasi daring selama masa pandemik Covid-19;

2) Pengawasan dilaksanakan dengan tujuan :

a. Klien tetap berada di rumah;

b. Klien melaksanakan program bimbingan;

c. Klien menjalin hubungan yang baik dengan keluarga dan lingkungan;

d. Klien dalam keadaan sehat.

3) Pengawasan klien/anak dilakukan oleh PK/APK dengan melaksanakan koordinasi dengan pihak-pihak terkait sesuai dengan perencanaan yang telah disusun;

4) Laporan pengawasan klien dibuat oleh PK/APK untuk diserahkan kepada Kabapas.

Alur pelaksanaan pengawasan dari awal sampai akhir dapat dilihat pada gambar berikut ini.

\footnotetext{
${ }^{30}$ Pemasyarakatan.
} 


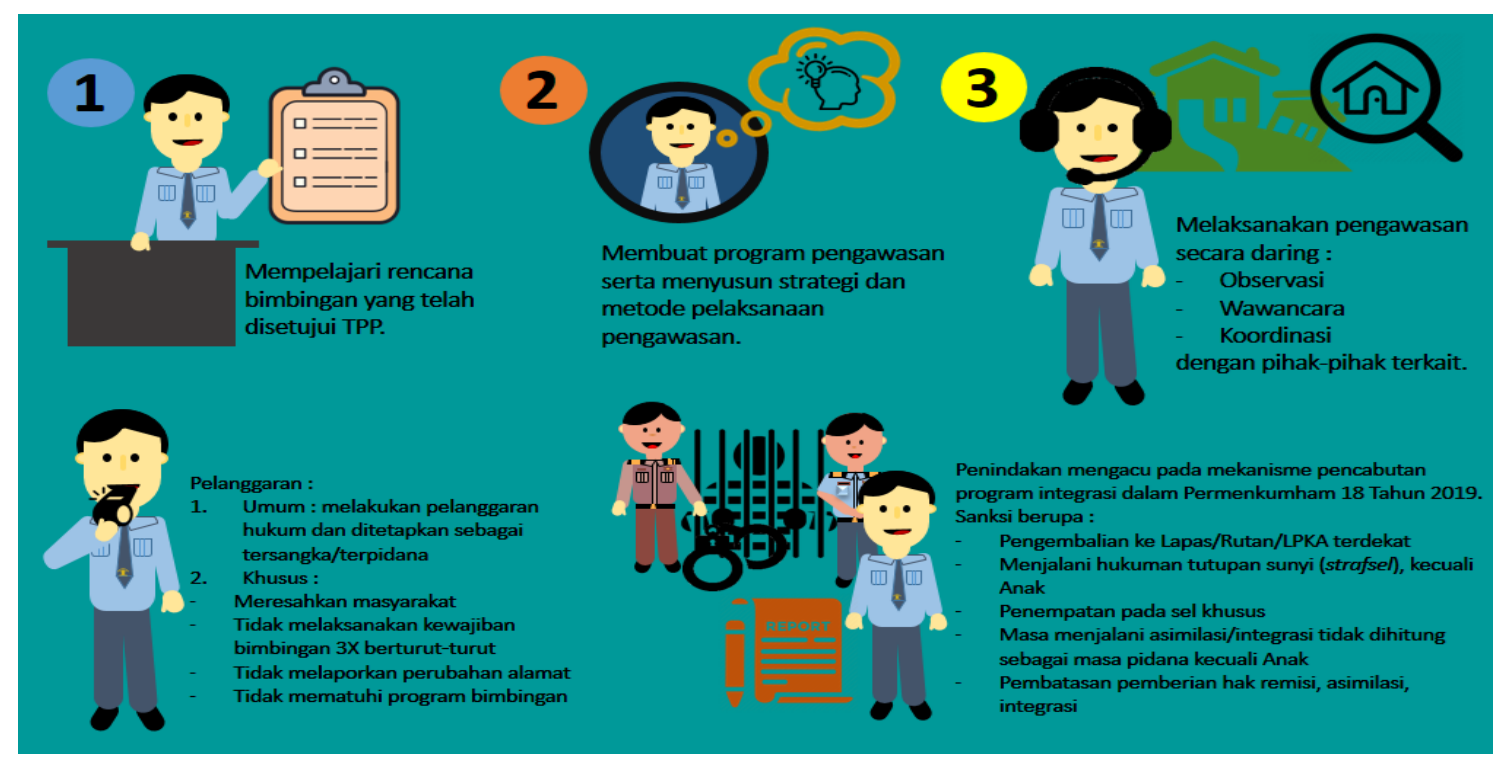

\section{Implementasi Permenkumham Nomor : 10 Tahun 2020 di Bapas Bandung}

Asimilasi adalah salah satu hak integrasi sosial yang diberikan kepada napi dan anak dengan cara membaurkan mereka ke masyarakat. ${ }^{31}$ Hak integrasi sosial yang juga diberikan antara lain cuti mengunjungi keluarga, cuti menjelang bebas, cuti bersyarat dan pembebasan bersyarat.

Para pelaksana agar lebih mudah melaksanakan permenkumham ini maka diterbitkan keputusan menteri tahun 2020 mengenai syarat-syarat pembebasan napi dan anak masa pandemik. Keputusan Menteri ini mengatur syarat-syarat narapidana dan anak yang dapat memperoleh hak integrasi. Mereka masuk dalam kategori PP 99 tahun 2012 tidak dapat diberikan haknya. ${ }^{32}$

Pelaksanaan permenkumham ini dilakukan secara serempak di seluruh Indonesia. Untuk narapidana dapat diusulkan hak integrasinya jika telah menjalani 2/3 masa pidana sampai dengan tanggal 31 Desember 2020. Anak yang diusulkan hak integrasinya apabila telah menjalani $1 / 2$ masa pidana sampai dengan tanggal 31 Desember 2020.33 Mereka yang telah memenuhi syarat administratif dapat diusulkan oleh lapas/rutan dimana yang bersangkutan menjalani pidana. Pengusulan dilakukan melalui Sistem Data Base Pemasyarakatan (SDP). Peraturan ini diberlakukan sampai dengan tanggal 31 Desember 2020.

31 “Peraturan Menteri Hukum Dan Hak Asasi Manusia Nomor 10 Tahun 2020 Tentang Syarat Pemberian Asimilasi Dan Hak Integrasi Bagi Narapidana Dan Anak Dalam Rangka Pencegahan Dan Penanggulangan Penyebaran Covid-19," 2020.

32 "Keputusan Menteri Hukum Dan Ham Nomor: M.HH-19.PK.01.04.04 Tahun 2020 Tentang Pengeluaran Dan Pembebasan Narapidana Dan Anak Melalui Asimilasi Dan Integrasi Dalam Rangka Pencegahan Dan Penanggulangan Covid-19.Pdf," 2020.

33 "Keputusan Menteri Hukum Dan Ham Nomor: M.HH-19.PK.01.04.04 Tahun 2020 Tentang Pengeluaran Dan Pembebasan Narapidana Dan Anak Melalui Asimilasi Dan Integrasi Dalam Rangka Pencegahan Dan Penanggulangan Covid-19.Pdf." 
Dalam permenkumham ini syarat penelitian kemasyarakatan (litmas) yang dibuat oleh PK sebagai syarat untuk asimilasi dan PB diganti dengan laporan perkembangan napi dan anak di lapas/rutan yang dibuat oleh wali pas/petugas. Selain itu syarat pihak keluarga sebagai penjamin juga diubah. Penjamin dapat dari petugas lapas/rutan ${ }^{34}$. Dampak tidak adanya penelitian kemasyarakatan (litmas) dan tidak adanya pihak keluarga sebagai penjamin menyebabkan PK tidak dapat melaksanakan tugas pembimbingan dan pengawasan secara maksimal. PK tidak mengetahui kondisi klien yang dibimbing dan tidak mengetahui keluarganya. Semua proses usulan asimilasi dan PB bagi narapidana dan anak, PK tidak dilibatkan. Hal ini disebabkan syarat penelitian kemasyarakatan (litmas) diubah dengan laporan perkembangan napi dan anak selama menjalani pidana serta petugas lapas/rutan dapat menjadi penjaminnya. PK baru mengetahui kliennya setelah dikeluarkan SK asimilasi dan PB yang diserahkan ke Bapas.

Dampak tidak adanya litmas serta tidak ada pihak keluarga sebagai penjamin menyebabkan banyak klien yang lost contact saat menjadi klien bapas. PK tidak mengetahui siapa yang akan dibimbing dan diawasi karena tidak pernah bertemu, tidak ada komunikasi karena tidak ada litmas. Dalam pembuatan litmas PK akan melakukan kunjungan atau home visit ke rumah klien. Permasalahan lain yang muncul ketika narapidana dan anak mencantumkan nomor telepon atau handphone maka yang diberikan oleh narapidana dan anak sebagian besar adalah nomor handphone petugas lapas. Akibatnya ketika PK menghubungi klien ke nomor tersebut tidak juga dapat dihubungi untuk melakukan bimbingan atau pengawasan karena nomor tersebut merupakan nomor petugas lapas. Ada juga narapidana dan anak yang mencantumkan nomor handphone pihak keluarga namun tidak bisa dihubungi karena tidak aktif lagi. Untuk mengatasi masalah tersebut PK melakukan kunjungan rumah atau home visit untuk memastikan alamat rumah klien, ternyata klien dan keluarga sudah pindah alamat karena rumah yang ditempati sudah habis masa kontraknya. Situasi-situasi seperti ini dapat diantisipasi PK jika ada litmas yang dibuat oleh PK. Dengan kondisi seperti itu maka berdasarkan data Bapas Klas I Bandung bulan Desember 2020 diketahui bahwa klien yang melakukan tindak pidana lagi ada 29 orang dan klien yang tidak dapat dihubungi atau lost contact sebanyak 635 orang dari 2.265 orang klien yang bebas karena Permenkumham ini.

\section{KESIMPULAN}

Hasil penelitian dapat disimpulkan antara lain pertama, terdapat banyak masalah dalam pelaksanaan permenkumham 10 tahun 2020. Kedua, permasalahan tersebut disebabkan oleh diubahnya penelitian kemasyarakatan (litmas) yang dibuat oleh PK sebagai syarat asimilasi dan PB dengan laporan perkembangan yang dibuat oleh petugas lapas/rutan. Ketiga, penjamin dapat dari pihak petugas lapas/rutan bukan pihak keluarga narapidana dan anak. Keempat, akibatnya banyak klien di

34 “Peraturan Menteri Hukum Dan Hak Asasi Manusia Nomor 10 Tahun 2020 Tentang Syarat Pemberian Asimilasi Dan Hak Integrasi Bagi Narapidana Dan Anak Dalam Rangka Pencegahan Dan Penanggulangan Penyebaran Covid-19." 
Bapas Bandung yang lost contact sebanyak 635 orang dan yang melakukan pengulangan tindak pidana ada 29 orang. Kelima, beberapa faktor yang menyebabkan klien lost contact antara lain pindah alamat, nomor penjamin yang digunakan nomor kontak petugas lapas/rutan, nomor kontak pihak keluarga sudah tidak aktif lagi. Keenam, proses pembimbingan dan pengawasan dilakukan oleh PK secara daring dari proses penerimaan sampai dengan pelaksanaan pembimbingan dan pengawasan. Ketujuh, tugas PK dalam penelitian kemasyarakatan, pembimbingan dan pengawasan tidak berjalan maksimal.

Dengan banyaknya persoalan yang terjadi maka sebaiknya pemerintah melakukan kembali evaluasi terhadap kebijakan ini. Faktor-faktor penyebab yang mengakibatkan proses penelitian kemasyarakatan, pembimbingan dan pengawasan tidak berjalan maksimal dapat dilakukan perbaikan.

\section{REFERENSI}

\section{A. Buku}

Prof. Dr. Kadji, Yulianto. Formulasi Dan Implementasi Kebijakan Publik: Kepemimpinan Dan Perilaku Birokrasi Dalam Fakta Realitas. Pertama. Gorontalo: Universitas Negeri Gorontalo Press, 2015.

Yin, Robert K. Qualitative Research from Start to Finish. 2nd ed. New York: The Guilford Press, 2016.

\section{B. Artikel/Jurnal}

Biafri, Vivi Sylviani, Kusmiyanti. "Impact of Over-Crowding In Correctional Institution On Health of Prisoner." In International Conference On Social Work In Health and Mental Health, 2018.

Sitohang, Rayambong Sumuang, and Kariono. “Implementasi Peraturan Pemerintah Nomor 65 Tahun 2010 Tentang Sistem Nformasi Keuangan Daerah Pada $\begin{array}{lllll}\text { Pemerintah Kabupaten Dairi" } & \text { 5, } 2015) \text {. }\end{array}$ http://ojs.uma.ac.id/index.php/adminpublik/article/view/72/30

Umronah, Enny. “Analisis Yuridis Pengawasan Asimilasi Dan Integrasi Bagi Narapidana Dan Anak Ketika Pandemi Covid-19 (Studi Di Balai Pemasyarakatan Kelas I Malang) -Enny." Legal Spirit 4 (2020). https://publishingwidyagama.ac.id/ejournal-v2/index.php/jhls/article/view/1554/1171.

Zakaria, Moh dan Sri Sulistijaningsih. “Tinjauan Hukum Terhadap Pelaksanaan Asimilasi Di Rumah Berdasarkan Keputusan Menteri Hukum Dan Ham Republik Indonesia Nomor M.HH-19.PK.01.04.04 Tahun 2020 Dalam Rangka Pencegahan Dan Penanggulangan COovid-19 Bagi Narapidana." Era Hukum 18 (2020): 156-81. https://journal.untar.ac.id/index.php/hukum/article/view/9932 


\section{Peraturan Perundang-undangan}

“Keputusan Menteri Kehakiman RI No. M.02-PR.07.03 Tahun 1987 Tentang Organisasi Dan Tata Kerja Balai Bimbingan Kemasyarakatan Dan Pengentasan Anak," 1987.

“Undang-Undang No. 12 Tahun 1995 Tentang Pemasyarakatan,” n.d.

“UU NO. 11 Tahun 2012 Tentang Sistem Peradilan Pidana Anak," 2012.

Pemasyarakatan, Direktorat Jenderal. Kompilasi Peraturan Perundang-Undangan Tentang Pembimbingan, 2015.

“PERMENPAN NO 22 Tahun 2016 Tentang Jabatan Fungsional Pembimbing Kemasyarakatan.Pdf," n.d.

"Pedoman Pelaksanaan Penelitian Kemasyarakatan Dan Pendampingan Secara Daring Serta Pembimbingan Dan Pengawasan Klien Asimilasi Dan Integrasi Dalam Rangka Pencegahan Dan Penanggulangan Covid-19," 2020.

“Peraturan Menteri Hukum Dan Hak Asasi Manusia Nomor 10 Tahun 2020 Tentang Syarat Pemberian Asimilasi Dan Hak Integrasi Bagi Narapidana Dan Anak Dalam Rangka Pencegahan Dan Penanggulangan Penyebaran Covid-19," 2020.

“Keputusan Menteri Hukum Dan Ham Nomor: M.HH-19.PK.01.04.04 Tahun 2020 Tentang Pengeluaran Dan Pembebasan Narapidana Dan Anak Melalui Asimilasi Dan Integrasi Dalam Rangka Pencegahan Dan Penanggulangan Covid-19.Pdf," 2020.

\section{Sumber Rujukan dari Website}

“135 Napi Asimilasi Kambuh," 2020. https://www.cnnindonesia.com/nasional/20200526081227-12-506870/135-napiasimilasi-kambuh-dari-faktor-ekonomi-hingga-dendam.

"Berulah Lagi, Napi Asimilasi Bakal Lebih Lama Dipenjara," n.d. https://lombokpost.jawapos.com/kriminal/29/07/2020/berulah-lagi-napi-asimilasibakal-lebih-lama-dipenjara/.

“Instagram Direktorat Jenderal Pemasyarakatan," n.d. https://www.instagram.com/p/CJvebM1LEMn/?igshid=wbdhpr9d7f5.

“Napi Dilepas Bikin Resah,” n.d. https:/www.cnnindonesia.com/nasional/20200426173911-12-497429/napi-dilepasbikin-resah-kebijakan-asimilasi-yasonna-digugat. 